\title{
Exploring the Institutional Market for Fresh Vegetables in the Southern Philippines
}

\author{
P.J. Batt \\ Curtin University \\ Perth \\ Australia
}

\author{
S.B. Concepcion \\ University of the Philippines in Mindanao \\ Davao \\ The Philippines
}

\section{M.T. Lopez \\ Professional Institute for Management Advancement \\ Manila}

The Philippines

J.T. Axalan, L.A.T. Hualda and M.O. Montiflor

University of the Philippines in Mindanao

Davao

The Philippines

Keywords: institutional markets, fresh produce, quality standards, buyers, suppliers

\begin{abstract}
Given the many different ways the product may be used, the institutional market for fresh vegetables in the Southern Philippines can be segmented on the basis of the role market intermediaries perform in the supply chain, where they are, what customers they serve, the range of products required, the volume of product required and the quality specifications. Potential market opportunities are identified and the various constraints smallholder farmers face in endeavouring to meet the needs of institutional buyers are highlighted.
\end{abstract}

\section{INTRODUCTION}

The consumption of fresh vegetables in the Philippines is currently estimated to be in the region of only $40 \mathrm{~kg}$ per capita (FNRI, 2002), well below the 146-182 $\mathrm{kg}$ per capita recommended by the FAO (2003). However, more recently, consumption patterns are changing, especially in urban areas. The increasing income of urban Filipinos is contributing towards an increase in the demand for high value vegetables, including salad vegetables. With a larger number of middle and upper income Filipinos shopping at supermarkets instead of the traditional wet markets, the supermarkets share of fresh produce sales has been steadily rising (Digal and Concepcion, 2008). Furthermore, the demand for more ready-to-eat and processed foods is accelerating, with a commensurate increase in the amount of food being consumed through the food service sector and fast food outlets.

These shifts in consumer demand suggest that a study of the institutional market for fresh vegetables in the Philippines is warranted. Upstream, there is an immediate need for both producers and market intermediaries to respond, for with the constant erosion of trade barriers, institutional buyers may find that they can more readily fulfil their needs through imports. 
To date, very few studies have sought to determine the institutional demand for fresh vegetables in the Philippines. The few studies that have been commissioned have been undertaken primarily in Metro Manila. However, regional differences in climate and topography will influence the range, the quality and the quantity of fresh vegetables available from local producers, and differences in household income, tourism, transport and infrastructure will shape both the institutional demand and the extent to which fresh vegetables are traded between regions.

\section{METHODOLOGY}

The objective of this study was to assess the institutional market for fresh vegetables in the Southern Philippines (Mindanao and the Visayas) by surveying buyers of fresh vegetables regarding: (1) the fresh vegetables required; (2) their current sources of supply; (3) to assess any unfilled needs and gaps in supply; and (4) to identify any opportunities to differentiate the product in the market. Potential niche markets for safe vegetables, organic, Fairtrade and hydroponic vegetables were explored.

In this study, information was collected through key informant interviews with buyers from the fast food industry, executive chefs, food service operators, wholesalers, consolidators and retailers, from the cities of Cebu, Bacolod, Iloilo, Tagbilaran, Dumaguete, Tacloban and Ormoc in the Visayas, and Davao City, Cagayan de Oro City and General Santos City in Mindanao. Interviews were conducted from September 2008 to February 2009. A total of 85 interviews were undertaken

Upon arrival in each research area, ocular surveys were done of the wet markets, supermarkets and other institutions that sold fresh vegetables. Visits to local government units (LGU), Department of Agriculture offices and other relevant government agencies and NGOs were undertaken in each location.

In order to analyse the data and to facilitate a comparison across markets and market segments, it was first necessary to establish an analytical framework. Following Infante (2003), the vegetable industry in the Philippines was initially classified into three groups: (1) the traditional pakbet vegetables included squash, bitter gourd, string beans and okra. These are the typical lowland (tropical) vegetables that are an integral part of the Filipino cuisine and are widely grown throughout the archipelago; (2) the chopsuey vegetables included the temperate (highland) vegetables like cabbage, sayote, broccoli, cauliflower, carrots and Baguio beans; (3) the salad vegetables included the leafy green vegetables used in fresh salads and culinary herbs such as basil, thyme, sage and rosemary. However, in light of the discussions with institutional buyers and users, it became apparent that a further classification was needed. This additional group included the spices and condiments that are frequently used in cooking and included garlic, onions, ginger and spring onion. This group was described as lamas.

With the rapid expansion of modern retail formats and vast differences in the disposable household income, the consumer market was segmented using socio-economic indicators proposed by Virola et al. (2007). AB households were defined as those having a monthly income of $\mathrm{PhP} 50,001$ and above. $\mathrm{AB}$ households live in well built subdivisions with concrete structures, with all utilities The household head usually occupies a top position in a company, or owns their own business. There are more households classified as AB in Metro Manila and Metro Cebu than in any other part of the country. The AB market tends to influence the demand for many consumer products which are adopted by other income groups as soon as less expensive versions of the product become available. They are also more educated, more adventurous, and more 
exposed to the various forms of media and communication. Mindanao has the least number of households which can be classified as AB.

C1 households are referred to as the upper middle class, with monthly family incomes of $\mathrm{PhP} 30,001$ - 50,000 per month. The heads of these households are mostly owners of small businesses, middle managers and junior executives within large companies. They reside mostly in subdivisions with homes having a mixture of concrete and wooden materials.

Broad $\mathrm{C}$ or the lower middle class are households with incomes of $\mathrm{PhP} 15,001-$ 30,000 per month, who live in less expensive houses with basic amenities. The occupations of these household heads are office workers, government employees and rank and file.

Households in the D class earn PhP 8,001-15,000 per month. Their houses are made of a mixture of cement and recycled materials, are usually small in size and located in the less expensive part of the city. Household members within the D classification are blue-collar workers, tricycle drivers, factory workers and the like.

The E households are those who barely have enough income to subsist. Many work irregularly, earning less than PhP 8,000 per month. The largest proportion of the D and E households are found in Mindanao and the Visayas (Castro, 2009).

\section{RESULTS}

In the institutional market, fresh vegetables are purchased for resale, for processing or for subsequent incorporation in food service operations. Not unexpectedly, given the many different ways in which the product is used, the institutional market was segmented on the basis of the role market intermediaries perform in the supply chain, where they are, what customers they serve, the range of products required, the volume of product required and the quality specifications.

Segment 1 was comprised of the five star hotels and tourist resorts, restaurants and the supermarkets catering to the wealthy $\mathrm{AB}$ consumers (Table 1). This market segment required the widest range of vegetables and was the most quality discerning. In most cases, formal product descriptions existed for each product. In addition, suppliers were required to operate under an approved food safety program and there was often a requirement for producers to adopt sustainable farming practices. Segment 1 purchased mostly salads and herbs and temperate chopsuey vegetables. While some of them served pakbet vegetables, these were provided to foreign tourists because they were traditional Filipino vegetables which were perceived to be exotic.

Segment 2 was composed of the business hotels and resorts who catered to business, government and those non-government institutions who conducted seminars and conventions and provided special functions for the $\mathrm{ABC} 1$ households such as weddings, debuts and anniversaries. This segment also included most of the mainstream supermarkets which serviced mostly urban consumers who valued the convenience of purchasing all their household needs from one shopping centre. These institutions purchased similar types of vegetables as Segment 1, but they were far more price conscious. Most of the food service institutions in Segment 2 were very flexible with the menu they offer. If for any reason the product is not available, a substitute product was offered or customers simply advised at the time that they placed their order that the product was not available. They rarely served salad vegetables and herbs, but needed a regular supply of chopsuey and pakbet vegetables. 
Segment 3 included the wholesalers and consolidators. Their customers included both traditional and modern retailers, food processing firms and hotels and restaurants. To service their different customers needs, they required a wide range of fresh vegetables. The better quality produce was sold to Segments 1 and 2, while the lower quality produce was delivered to other institutional markets.

Segment 4 accounts for 75 - 80\% of the retail sales of fresh vegetables in the Philippines. Households, restaurants and many hotels purchase the fresh vegetables that they require from retailers in the traditional wet market. This segment catered to the $\mathrm{C} 2$ and DE market segments. Quality requirements were not very strict and the range of products quite narrow, for only the traditional pakbet vegetables were purchased. In this segment, the demand for the temperate chopsuey vegetables was low and the demand for salad greens and herbs almost non existent. For this segment, price was the most important variable in the decision to purchase.

\section{Sources of Supply}

In any analysis of fresh vegetable supply chains in the Philippines, it is essential to differentiate between the pakbet and chopsuey vegetables. The pakbet vegetables include those traditional, tropical lowland vegetables that are often intercropped with rice and maize and are an integral part of traditional Filipino diets. With the notable exception of tomato, the trade in these products occurs primarily between proximate rural and periurban areas and the immediately adjacent urban centres. There is very little inter-island trade because of the widespread availability of these products, and, except for natural catastrophes such as floods and typhoons, the high costs of transport make the product too expensive for low income consumers to purchase.

In the tropics, altitude is able to substitute for latitude. Hence, the production of the chopsuey vegetables occurs primarily in the highland regions. Given its close proximity to Metro Manila, the main area for the production of highland vegetables is the Cordillera Administrative Region (CAR)(76\%). Mindanao (19\%) and the Visayas (4\%) are the two other notable producers of temperate vegetable crops (Remotigue, 2005).

In the highlands, the production of the temperate chopsuey vegetables is very much dependent on the climate in the region. During the typhoon season, heavy rain and wind will not only destroy the crops, but the instability of the land often results in the closure of both arterial and main roads, thereby making it impossible to transport whatever product has been spared. As there is much variability in the climate types and the intensity and duration of the typhoons across the archipelago, farmers often plant vegetables in the expectation that typhoons elsewhere will significantly reduce the quantity of fresh vegetables available with a commensurate increase in price.

Given the high incidence of typhoons in Luzon from June to November, vegetable growers in Mindanao have traditionally planted tomatoes and cabbages to meet the anticipated shortfall in production. Not unexpectedly, there is a high element of risk, for in those seasons when the typhoons do not come, the supply from the CAR does not diminish and prices do not increase. Nevertheless, to meet the needs of an emerging middle class and the increasing number of foreign tourists, the institutional demand for chopsuey vegetables, salad greens and lamas is increasing. As many of the islands in the Visayas are currently unable to produce sufficient quantities of chopsuey vegetables, there is a significant inter-island trade.

The ease with which fresh vegetables move between the islands and their subsequent availability is very much dependent upon the frequency of shipping and 
flights, the level of infrastructure in terms of the extent to which the islands are connected by a road system and the nature of the long-term relationships between trading partners.

In sourcing the fresh vegetables that they require, the majority of institutional buyers rely upon preferred suppliers (suki) to provide them with the quantity and range of product that they require. Given the highly unpredictable nature of supply and significant variations in product quality, most institutional buyers have more than one supplier. Such greatly extends their marketing reach, thereby increasing the possibility of securing the products required, whilst simultaneously providing a means by which the quality of the product offered and the price can be readily compared with alternative offers.

With the advent of modern telecommunication systems, many alternative sources of supply and the extensive networks that often evolve between market intermediaries, buyers are readily able to determine the price for those products which meet their specifications from each alternative source of supply. Where there is an opportunity to make additional profit by importing product at a lower cost, product will move into that market. Thus the price at which fresh vegetables are sold is determined by the cost of that product from the best alternative source plus the cost of transport.

When supplying to the supermarkets, five star hotels and resorts, preferred suppliers must not only meet defined quality specifications, but the prices for that product which meets specifications is often established in advance. Given the unpredictable nature of supply in the Philippines, wholesalers and consolidators are free to purchase from wherever they can secure the best quality product at the most competitive price. However, significant penalties may also be imposed upon those suppliers who fail to deliver on time and to the quantities as specified.

As product shortages do inevitably arise, a significant amount of trade occurs between the different types of institutional market. Where preferred suppliers are unable to deliver what the restaurants want, they often source the product from supermarkets. For the five star hotels and tourist resorts, fast food companies and food processors, when the product is not available in the Philippines, they will import either directly or indirectly via Metro Manila.

So as to minimise their exposure to the financial risks associated with product losses arising from poor quality, poor post-harvest handling and product deterioration over time (shelf life), many of the supermarkets have invited concessionaires to manage and to operate the fresh produce department in-store. In accepting the offer, it is the concessionaires' responsibility to stock the shelves, to wrap and to price the product, to prepare any pre-cut vegetable mixes, salad mixes etc., and to remove any unsold product. In return, the concessionaires pay a predetermined percent of sales to the supermarket. As it is not uncommon for two or more concessionaires to operate within the one store, as differences in both the quality and price are apparent, consumers may become easily confused.

\section{Projected Requirements}

The quantity and the range of fresh vegetables required is very much dependent on the role played by the institutional buyer and the target market (Figure 1).

At the farm level, collector agents and traders accumulate bulk, create assortment and arrange for the transport of the fresh produce to market. In the wholesale market, wholesalers and consolidators purchase large volumes of many products from many alternative suppliers in order to fulfill the need of their downstream customer's. At the 
same time, as small retailers and food service customers purchase what they need, wholesalers are breaking bulk.

For the larger supermarkets, wholesalers and consolidators may be involved with grading, sorting, trimming and pre-packing, labeling and even pricing the product. To a lesser extent, some value-added activities may also be undertaken to prepare that product which is destined for the food service market, where the product is trimmed, peeled or pre-cut. Many wholesalers and consolidators also pack and arrange for the transport of fresh produce to other more distant markets where local growers cannot supply the product, the quality is poor, or there is an opportunity to on-sell the product at a profit.

Given the diversity of the actors involved in the supply chain and the activities that they may or may not perform, there is a significant difference in the projected requirements for fresh vegetables not only across the many different institutional markets, but also between the actors themselves. At the wholesale level, it would not be unusual for a trader to handle $2000-5000 \mathrm{~kg}$ of fresh vegetables per week. While a small retailer operating in a traditional wet market might handle only $200 \mathrm{~kg}$ per week, a modern supermarket could accommodate $55,000 \mathrm{~kg}$ per week.

For those firms catering to foreign tourists and the more affluent AB social class, there is a need to provide more temperate chopsuey vegetables, salad greens and herbs and lamas. Conversely, those providing fresh vegetables to the mainstream consumer market (Class C), canteens and carenderia, will need to supply primarily pakbet vegetables, some chopsuey vegetables and some lamas. The demand for salad greens and herbs is expected to be minimal, for the majority of Filipinos are still very wary of consuming raw, uncooked vegetables.

\section{Unfulfilled Needs}

The majority of the problems arise with the high value, chopsuey vegetables, leafy green vegetables and herbs. Despite the significant movement of fresh produce from the highland areas of production to the lowland areas of consumption, between different islands and different climatic zones, the supply is often insufficient to meet the demand and the quality poor.

Although such shortages are only temporary, the greater the distance and the more time the product is in transit, the greater the problem. This is a direct consequence of the lack of infrastructure, poor post-harvest handling and transport. In the absence of appropriate cool storage, leafy green vegetables wilt very quickly. In a tropical climate, as high temperatures are often accompanied by high humidity, rots and moulds proliferate and the incidence of insect pests (grubs and worms) is high.

For those institutional markets that service the five star tourist hotels and resorts, the up-market restaurants and retailers, the non availability and poor quality of the salad greens (lettuce), fresh herbs and lamas, present the greatest problems. As these products must be available, buyers often go to great lengths to assure supply through either purchasing from multiple suppliers or importing. For this market segment, other opportunities identified included baby or gourmet vegetables, mushrooms and specialty vegetables such as asparagus, celery and leeks, which are not always available in sufficient quantities.

For those who wish to supply fresh vegetables to this segment, not only must the product meet prescribed standards, there are often multiple specifications for one product, depending upon how it is used. Furthermore, these standards are highly subjective and very much dependent on the quality of the fresh produce available. When there is a 
shortage, in order to secure a sufficient quantity of produce to meet the anticipated demand, the standards may be relaxed, but when supply is plentiful, the standards will be rigorously enforced. To reduce costs and preparation time in the kitchen, not only must the product be washed, trimmed and any external packaging removed, but for products such as garlic, ginger and onions, the product may need to be peeled. Potentially, for those market intermediaries supplying this market, this creates an additional opportunity to add value. However, the quantities purchased are often small and delivery on a daily basis is required to retain freshness.

At the other end of the market, few institutional buyers raised any issues with regard to either the sufficiency of supply or the quality of the traditional pakbet vegetables. As these products are widely available from the peri-urban regions that are adjacent to most urban centres, the product needs to be transported only a short distance. Furthermore, supplies can be renewed on almost a daily basis. In this market segment, that product which begins to deteriorate because it has not been sold or it has become infected with an insect pest, is often cut and incorporated into a variety of vegetable mixes which other than cooking require minimal to no preparation.

\section{Differentiating the Product}

Most institutional buyers associate one or more vegetables with a particular region or area of production. Baguio was primarily associated with the temperate chopsuey vegetables. Most buyers preferred to purchase fresh vegetables from Baguio on the basis that they were perceived to be better quality, they looked better and in some instances, the product had a superior taste. Mindanao was most often recognised as an alternative source of supply for the chopsuey vegetables. However, product from Mindanao was preferred in the Visayas because of its lower price and more widespread availability.

While most institutional buyers failed to associate any of the tropical lowland vegetables with a particular region or area, most buyers preferred to purchase leafy green vegetables from "local" sources, as these were perceived to be fresher.

In many instances, buyers did not associate the quality of the fresh vegetables with the region in which it was grown, but rather the place from which it had been shipped (Cebu) or despatched (Metro Manila). Product from Cebu was often perceived to be fresher because it was closer, but product may have been sourced initially from Bacolod, Canlaon or Mindanao and even from Metro Manila.

However, given the importance of price in the institutional market, assuming that product is plentiful, the quality is comparable and product is available from a number of alternative sources, there was no evidence to suggest that institutional buyers were prepared to pay any more to procure fresh vegetables from their preferred source or origin. In many instances, because of the seasonality of supply or infrequent delivery, buyers had no choice other than to purchase whatever product was available.

In purchasing fresh vegetables institutional buyers generally believe that the product is safe to eat. However, fresh vegetables are often contaminated with soil, heavy metals, chemical residues and of most concern, pathogenic micro-organisms. While many institutional buyers require their suppliers to introduce quality assurance systems as a means of ensuring that they have taken "all reasonable steps" to assure consumers that the food is safe to eat, producers are unlikely to receive any price premium. If they wish to supply these institutional buyers, they must either operate under a third party certified quality assurance system or risk exclusion from the market. 
While attaching a label to the product aims to convey information which persuades a potential buyer about the quality, reliability, value for money or safety of the product (Bowbrick, 1992), unless the firm is sufficiently large to have complete control of the production and distribution of the product from the farm to the retail shelf, producers are unlikely to achieve any benefit from branding. In the traditional marketing system where wholesalers and consolidators aggregate and mix the product received from many alternative suppliers, branding is unlikely to be of any value, and may even prove to be detrimental. However, many of the larger corporations such as Dizon, Dole and Eden have been successful in establishing brands, albeit that their product is only available in the supermarkets or through specialist wholesalers and provedores who supply the five star hotels, resorts and up-market restaurants.

In any discussion of organics in the Philippines, it is important to make the distinction between that product which is certified and that which is not. In much of the Philippines, organics refers to a low input method of production which uses natural inputs including animal manures, fermented plant juices, composts and vermiculture as a means of reducing the amount of chemical fertilisers and pesticides applied. However, this system of production does not preclude the use of chemical fertilisers or pesticides: farmers choose to sacrifice yields in the interests of reducing costs and thus their exposure to financial loss as a result of crop failure, brought about by the untimely arrival of the typhoons or heavy rain, or inordinately low prices in the market as a consequence of supply exceeding demand.

Within the Philippines, even although organic produce is widely perceived to be more healthy, the majority of institutional buyers are unwilling to pay any price premium to procure organic produce. For those businesses supplying the traditional wet market, local restaurants and carenderias, and even large, multinational food processors, as price is the key purchasing criteria, they are unable to pass on the additional costs to consumers. However, among the five star hotels, tourist resorts and those retailers who supply fresh vegetables to the wealthy $\mathrm{AB}$ consumer group, potential premiums of between 10 - 50\% may be available for organic produce.

\section{IMPLICATIONS FOR SMALLHOLDER VEGETABLE PRODUCERS}

If smallholder vegetable producers are to access higher value institutional markets, it will be mandatory for them to first establish some collaborative marketing group. This will greatly enhance their capacity to meet the customer's specifications in terms of the quantity and quality of the product and perhaps even to extend the range of product offered. However, a number of constraints may impede their capacity to transact: (1) the need to be legally registered and incorporated; (2) the high costs of implementing third party certified quality assurance systems; (3) the need for credit, as many institutional buyers pay 30-90 days after delivery, and where required, cash to purchase inputs such as seed, chemicals and fertilisers and protected rainshelters; (4) the need for technical information, as farmers often lack the skills required to cultivate the crops in demand; and (5) the need, at group level, to commit to the market. For most smallholder producers, this means being willing to forego short-term price incentives in order to secure long-term markets. Failure to do so may result in downstream buyers entering into long-term relationships with more reliable suppliers, thereby leaving smallholder producers with no alternative other than to transact with the traditional markets, where the prices are highly volatile occasioned, by the day-to-day variation in supply. 


\section{ACKNOWLEDGEMENT}

This study was funded by the Australian Centre for International Agriculture Research (ACIAR) under Project HORT/2007/066, Enhanced profitability of selected vegetable value chains in the Southern Philippines: Component 4: Value Chain Analysis.

\section{Literature Cited}

Bowbrick, P. 1992. The Economics of Quality, Grades and Brands, Routledge Publishers. Castro, L. 2009. 2006 Poverty Statistics for the Basic Sectors. Presented at the Users' Forum on the 2006 Poverty Statistics for the Basic Sectors and 2006 Child Development Index at Makati City, June 25, 2009. National Statistical Coordination Board.

Digal, L.N. and Concepcion, S.B. 2008. Small producer groups in restructuring Philippine vegetable industry. In Batt, P.J. (ed). Proceedings of the Second International Symposium on Improving the Performance of Supply Chains in the Transitional Economies. Acta Hort 794: 99-106.

FAO. 2003. Increasing fruit and vegetable consumption becomes a global priority. http://www.fao.org/english/newsroom/focus/2003/fruitveg1.htm

FNRI. 2002. Philippine Nutrition, Facts and Figures. Part 1: Dietary. FNRI-DOST. http://www.fnri.dost.gov.ph/facts/table5.html

Infante, M.N. 2003. Status of the Vegetable Industry in Southern Mindanao, paper presented at the Policy Forum, Towards a more efficient vegetable supply chain: prospects and challenges. SEARCA, Los Banos, Laguna.

Remotigue, M.E. 2005. The Mindanao vegetable industry situation. Proceedings of the Second Mindanao Vegetable Congress. Grand Men Seng hotel. Davao. August 18-19.

Virola, R.A., Addawe, M.B. and Querubin, M.I.T. 2007. Trends and Characteristics of the Middle-Income Class in the Philippines: Is it Expanding or Shrinking? Paper presented during the $10^{\text {th }}$ National Convention on Statistics (NCS), EDSA Shangri-La Hotel, Metro Manila.

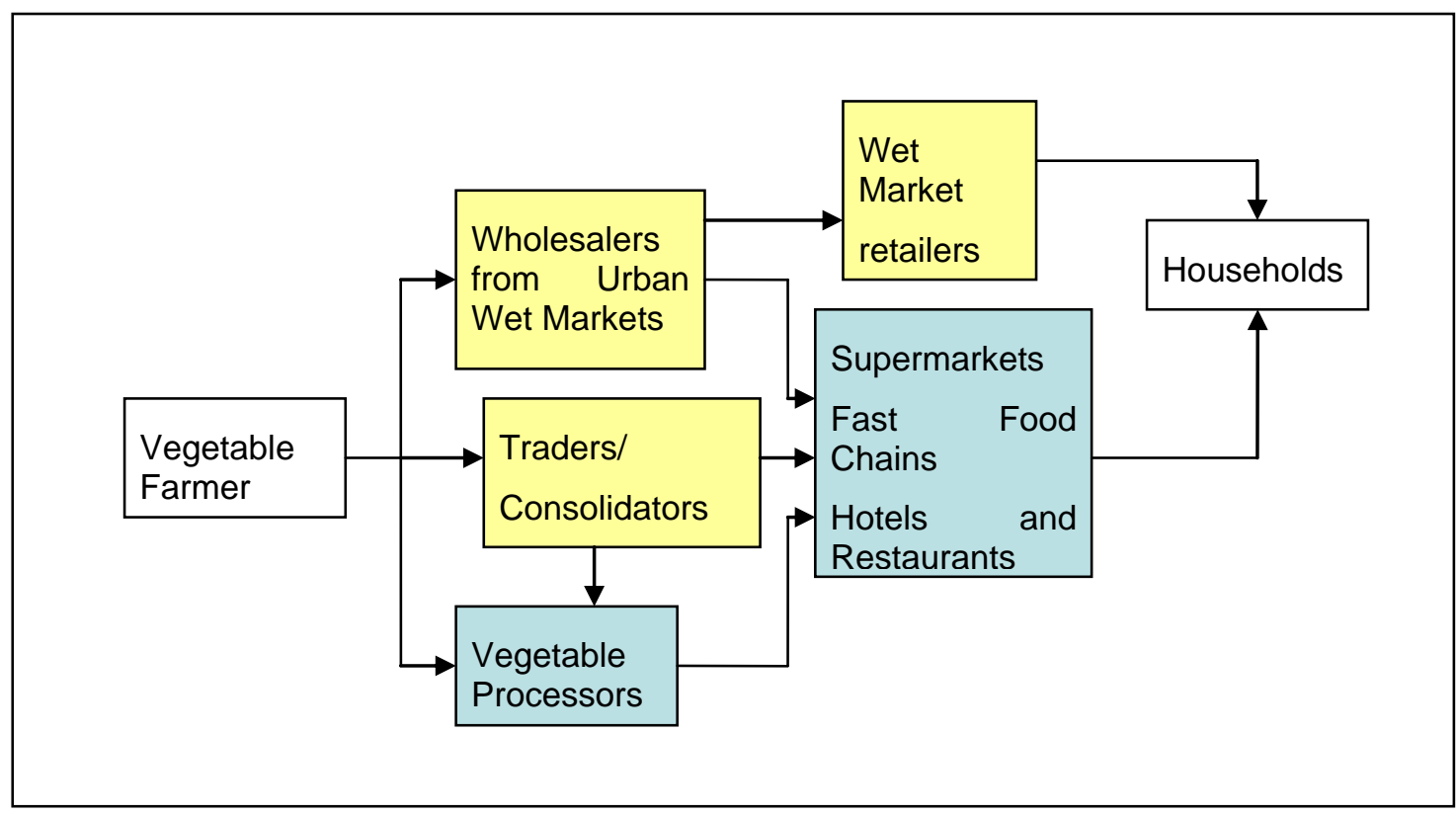

Figure 1: The Philippines vegetable supply chain 
Table 1: Attributes of different institutional markets for vegetables

\begin{tabular}{|c|c|c|c|c|}
\hline Attributes & Segment 1 & Segment 2 & Segment 3 & Segment 4 \\
\hline Who they are & $\begin{array}{l}\text { Up-scale hotels, } \\
\text { resorts, } \\
\text { restaurants, some } \\
\text { supermarkets }\end{array}$ & $\begin{array}{l}\text { Business hotel } \\
\text { Mid priced } \\
\text { resorts } \\
\text { Supermarket } \\
\text { chains }\end{array}$ & $\begin{array}{l}\text { Restaurants with } \\
\text { catering } \\
\text { Wholesaler- } \\
\text { consolidators }\end{array}$ & $\begin{array}{l}\text { Wet market } \\
\text { retailers, } \\
\text { carenderia, } \\
\text { canteens }\end{array}$ \\
\hline $\begin{array}{l}\text { Customers } \\
\text { Who they serve }\end{array}$ & $\begin{array}{l}\text { Foreign tourists } \\
\text { Class AB } \\
\text { Filipinos }\end{array}$ & $\begin{array}{l}\text { ABC1 } \\
\text { Expatriates } \\
\text { Budget tourists } \\
\text { Convention } \\
\text { market }\end{array}$ & $\begin{array}{l}\text { Segment } 1,2 \& 4 \\
\text { (for the } \\
\text { consolidators) } \\
\mathrm{C} 1 \text { and } \mathrm{C} 2 \\
\text { Government } \\
\text { agencies } \\
\text { Local business } \\
\text { and NGOs }\end{array}$ & C2 DE \\
\hline $\begin{array}{l}\text { Geographic } \\
\text { concentration }\end{array}$ & $\begin{array}{l}\text { Metro Manila, } \\
\text { Metro Cebu, } \\
\text { Boracay, Panglao }\end{array}$ & Urban centres & $\begin{array}{l}\text { Widely dispersed } \\
\text { across the } \\
\text { country, esp in } \\
\text { urban and } \\
\text { urbanizing areas }\end{array}$ & $\begin{array}{l}\text { Widely dispersed } \\
\text { across the } \\
\text { country }\end{array}$ \\
\hline $\begin{array}{l}\text { Technical } \\
\text { quality }\end{array}$ & High & Medium to high & Low to high & $\begin{array}{l}\text { Low, very price } \\
\text { conscious }\end{array}$ \\
\hline $\begin{array}{l}\text { Range of } \\
\text { products }\end{array}$ & $\begin{array}{l}\text { Very broad } \\
\text { Salads, herbs \& } \\
\text { spices, chopsuey, } \\
\text { some tropical } \\
\text { vegetables, lamas }\end{array}$ & $\begin{array}{l}\text { Narrow, each } \\
\text { institution has a } \\
\text { select repertoire } \\
\text { of vegetable } \\
\text { needs } \\
\text { Chopsuey, } \\
\text { pakbet }\end{array}$ & $\begin{array}{l}\text { Broad range, in } \\
\text { order to supply } \\
\text { their markets } \\
\text { Salads, herbs and } \\
\text { spices, chopsuey, } \\
\text { pakbet, lamas }\end{array}$ & $\begin{array}{l}\text { Narrow } \\
\text { Some temperate, } \\
\text { mostly pakbet, } \\
\text { lamas }\end{array}$ \\
\hline $\begin{array}{l}\text { Volume } \\
\text { required }\end{array}$ & $\begin{array}{l}\text { Low volume but } \\
\text { wide assortment }\end{array}$ & $\begin{array}{l}\text { Medium volume, } \\
\text { more than } \\
\text { segment } 2 \text { but } \\
\text { less than } \\
\text { segment } 3\end{array}$ & Large & $\begin{array}{l}\text { Largest, most } \\
\text { volume required } \\
\text { of a narrow } \\
\text { range of } \\
\text { products } \\
\end{array}$ \\
\hline Convenience & $\begin{array}{l}\text { Minimally } \\
\text { processed for } \\
\text { some of them } \\
\text { required but not } \\
\text { all }\end{array}$ & $\begin{array}{l}\text { Availability and } \\
\text { price }\end{array}$ & $\begin{array}{l}\text { Availability and } \\
\text { price }\end{array}$ & $\begin{array}{l}\text { Minimally } \\
\text { processed } \\
\text { vegetables } \\
\text { salvaged from } \\
\text { produce that sold } \\
\text { in previous days, } \\
\text { purchased due to } \\
\text { lower price aside } \\
\text { from } \\
\text { convenience }\end{array}$ \\
\hline $\begin{array}{l}\text { Credence } \\
\text { attributes }\end{array}$ & Aware & Not very aware & Not aware at all & Not concerned \\
\hline
\end{tabular}

